\title{
In-service Science Teachers' Readiness of Integrating Augmented Reality
}

\author{
Mustafa Jwaifell ,* $^{*}$ \\ ${ }^{1}$ Faculty of Education, Al-Hussein Bin Talal University, Ma'an, Jordan \\ *Correspondence: Faculty of Education, Al-Hussein Bin Talal University, P.O. Box: 20, Ma'an, Jordan. E-mail: \\ jwaifell@ahu.edu.jo \& jwaifell@thotmail.com.https://orcid.org/0000-0002-7279-7253
}

Received: May 6, 2019 Accepted: May 21, 2019 Online Published: May 23, 2019

doi:10.5430/jct.v8n2p43 URL: https://doi.org/10.5430/jct.v8n2p43

\begin{abstract}
This paper investigates the readiness degree among in-service science teachers in Ma'an Governorate for integrating augmented reality in teaching according to Technological, Pedagogical and Content Knowledge TPACK framework and its domains. The study sample consisted of (60) in-service science teachers enrolled voluntary in the study. The researcher used descriptive statistics, ANCOVA and T-test. The data analyses revealed significant differences among teachers' readiness in a high degree. Paired sample t-test showed female teachers' readiness higher than male teachers at all of the TPACK the domains. Results of ANCOVA revealed that experience of teachers' readiness do not differ significantly. The study recommended the focus on integrating augmented reality within learning environments.
\end{abstract}

Keywords: augmented reality, TPACK, in-service science teachers, readiness, skills, teachers training, Jordan

\section{Introduction}

Technologies has hugely impacted and invaded all fields of life including education. Nowadays there are many obstacles, barriers, and challenges facing teachers in understanding the way of integrating and incorporating those technologies effectively in educational settings. Still adopting new technologies in education is hugely affected by teachers acceptance, readiness, and their ICT involvement in pre-lin-service teacher training to evoke their competencies into a proper level (Jwaifell, M., Abu-Omar, A., \& Al-Tarawneh, M. 2018). Teachers need to possess more competencies to integrate ICT in learning and teaching environments. To assure ICT competencies, integration should emphasize pedagogy and content as scholars suggested the technological pedagogical content knowledge (TPACK) framework (Mishra \& Koehler, 2006) to have a clear picture of how ICT related to curricula components.

Augmented Reality is one of multiple media integrated learning application Which offers a new bright light into the learning process and forces learners' to represent information and knowledge in a new and innovative way where it can enhance both teachers and learners motivation to provide a rich learning and teaching environment.

\subsection{Augmented Reality}

Augmented Reality (AR) comprises of three fundamental criteria for its application: a combination of real and virtual world, interactivity in real time environment and has to be registered in three dimensions form (Azuma, 1997). By this definition, AR is a variation of environment designed in a virtual aspect, or as commonly called Virtual Reality which immerses a user inside a synthetic environment. But the most distinguish techniques used is allowing the students to enrolled in rich virtual environment and seeing the real world at the same time.

\subsubsection{Augmented Reality and Its Role in Learning}

This dynamic complex environment allow students to think more about using technologies (Leinhard \& Greeno, 1986; Spiro, Fletovich, Jacobson \& Coulson, 1991) while teachers need to have more competencies to practice and design learning teaching environment and situations based on those technologies and this diverse of components that motivates students to be more interactive.

The AR integrate what is real within a virtual world where they achieve cognitive, affective, and psychomotor objectives by interacting with virtual objects to be performed through real world tasks while using the computer as a tool to make those tasks or problems to be solved much easier to perform without having risks of injury, limited time, or more costs especially in learning science such as physics or engineering. 
It cannot be denied that AR has been used in all fields starting with military to marketing. The earliest applications of AR were in gaming, medical, and engineering, but the most interesting applications were in educational situations to bridge the gap between real and virtual worlds and at the same time the learner will become part of this combination. The previous applications in education were projects that encourage children to learn about scientific processes (Rogers, Price, Randell, Stanton Fraser, Weal, \& Fitzpatrick, 2005) and exploration of physical environment (Klopfer \& Squire, 2008).

Researchers have explored those uses within a variety of disciplines such as the medical applications which have been examined by Liu, Jenkins, Sanderson, Fabian, \& Russell (2010), while other researchers have focused their work on AR applications on mathematics and geometry through creating an AR system for facilitating learning and teaching situations between students and their teachers (Kaufmann \& Dünser, 2007; Kaufmann \& Schmalstieg, 2003). AR can be used in education in different ways. Yuen, Yaoyuneyong, and Johnson (2011) pointed to five significant educational applications of AR technology: AR books, AR gaming, discovery-based learning, objects modeling, and skills training.

Exploring students and teachers perceptions, using, or impact of AR on learners achievements are still in need beside the necessarily more research about the behavior of AR in teaching situations (Cabero \& Barroso, 2016). For example Agbo-Egwa, Abah, and Abakpa (2018) examined the students' perceptions of tech-augmented learning in basic mathematics through a questionnaire to measure their perceptions, the results showed a high positive perceptions and the students expressed that they liked the tech-augmented activities. While Luckin \& Fraser explored (300) participants for evaluating AR in schools and homes, their findings supported the claim that AR has the potential to promote learning and motivate children to engage with learning activities. Gopalan et al (2015) evaluated the (E-star application) to enhance science textbook using AR among secondary students, where they found that e-star application can be one of the potential solutions to motivate learners and to be a source for Malaysian students. Beside the work of Goplan, Zulkifli and Abu Baker (2016) in determining whether the intervention of the enhanced science textbook using AR contributes to the learning process of the students in science, the result they reached supported the relationship between engaging, enjoyment and fun. Presently, there is a study of using the mobile AR for physics experiments (Abubakar et al., 2018). Delello (2014) investigated pre-service teachers using science-based AR, where he concluded the potential of AR to positively impact classroom learning experiences.

\subsubsection{Elements of Technological, Pedagogical, and Content Knowledge}

Based on Shulman's construct of Technological, Pedagogical, and Content Knowledge (TPACK), which is a triad construct representing teacher knowledge for technology integration, or the knowledge intersections technology, pedagogy, and content as a core components (Mishra \& Koehler, 2006), scholars investigated (TPACK) framework and analysed teachers' knowledge, readiness and perceptions in educational sciences (Cox \& Graham, 2009; Niess et. al, 2009; Groth, Spickler, Bargner \& Bardzell, 2009; Chi, Koh, Tsai, \& Tan, 2011; White \& Geer, 2013). TPACK consists of seven elements:

Content Knowledge (CK): Teachers' knowledge of the subject matter they teach to their students involving knowledge of epistemology levels (facts, concepts, roles, theories); Pedagogical Knowledge (PK): Teachers' knowledge of methodologies of teaching and learning; Technology Knowledge (TK): Knowledge of thinking about, and working with technology tools and resources; Pedagogical Content Knowledge (PCK): Transformation of the subject matter for teaching; Technological Content Knowledge (TCK): It is about how teachers' understanding of technology and their understanding of content influence one another; Technological Pedagogical Knowledge (TPK): The change of teaching and learning when particular technologies are used in particular ways, Technological Pedagogical Content Knowledge (TPCK): The meaningful and deeply skilled teaching with technology (Koehler \& Mishra, 2009).

Researchers used TPACK to examine teachers' perceptions in science classrooms through questionnaire (Jang, 2010; Jang \& Chen, 2010; Trautmann \& MaKinster, 2010; khan, 2011; Hechter, 2012; Jang \& Tsai, 2012; Lin et al., 2013) and the results indicated that teachers' perceptions are correlated positively with TPACKS domains.

The researchers examined a variety of technological tool to be integrated in teaching such as: whiteboards, mind-mapping tills, geospatial technology, and other using simulations programs. The concentration in this study is on AR as one of the e-learning tool, which are as the researcher knowledge there is a paucity in the literature that examined integrating AR in teaching science and understanding teachers' readiness for integrating AR in teaching in the Arab countries. 


\subsubsection{Rational of the Study and Research Questions}

In this study, based on researchers' experiences in teaching hundreds of in-service teachers, graduated students (diploma, master and $\mathrm{PhD}$ ), Science teachers still lack competencies to use technologies in their practice especially in the southern part of Jordan. The force of policy makers and technologies itself, reveal the need of such readiness to use technologies. There still is a shortage of research of science teachers readiness of using new technologies such as Augmented Realty, therefore this study was conducted under the claim that in-service science teachers in Ma'an Directorate have no prior knowledge about augmented reality thus their readiness in the use of this technology limited. Therefore, this study is aimed at determining Ma'an Directorate science teachers' readiness for integrating augmented reality, by answering the following questions:

1) What are the changes of readiness degree of in-service science teachers in Ma'an Directorate for integrating augmented reality in teaching according to TPACK framework and its domains?

2) Do male and female in-service science teachers in Ma'an Directorate differ in their readiness for integrating augmented reality in teaching according to TPACK framework and its domains?

3) Do years of experience of in-service science teachers in Ma'an Directorate have an effect on their readiness for integrating augmented reality in teaching according to TPACK framework and its domains?

\section{Method}

The study adopted a descriptive research design. The researcher conducted a survey using a measurement tool for collecting data on the readiness degree of Ma'an Directorate in-service science teachers for integrating augmented reality in teaching according to TPACK framework and its domains.

\subsection{The Study Population and Sample}

The sample of this study consisted of (60) in-service science teachers in Ma'an Governorate. All the participants enrolled voluntary in two hours presentation demonstrating augment reality and received a brochure explaining its role and how to use it. The questionnaires were gathered to be analyzed:

Table 1. The Study Population and Its Sample

\begin{tabular}{llll}
\hline \multirow{2}{*}{ Years of Experience } & \multicolumn{2}{l}{ Gender } & \multirow{2}{*}{ Total } \\
\cline { 2 - 3 } & Male & Female & \\
\hline $1-5$ & 14 & 13 & 27 \\
$6-10$ & 12 & 11 & 23 \\
More than 10 & 6 & 6 & 12 \\
Totals & 30 & 30 & 60 \\
\hline
\end{tabular}

The researcher' main concern was to measure the readiness degree of Ma'an Governorate in-service teachers science teachers for integrating augment reality in teaching according to TPACK framework and its domains in order to understand the whole picture of their aptitudes and give recommendations to the administration of Ministry of Education in Jordan, and universities for better understanding when planning for teachers' training and pre-service training. All the teachers in the study have Bachelor's degree and none of them hold a diploma.

\subsection{Ethics}

The study as a whole was approved by the Directorates of Education for the Governorate of Ma'an, in addition it was approved by Al-Hussein Bin Talal University Research Ethics Committee at the Faculty of Education.

\subsection{The Measurement Tool}

The study developed and modified the TPACK framework used by (Almalaheem, 2016, Jwaifell, M., Abu-Omar, A., \& Al-Tarawneh, M. 2018) as a measurement tool for measuring the readiness degree of the teachers. When analyzing the items content, it appeared to the researchers and the four referees that those items did not have any cultural biases and not commonly applicable to the teachers in Jordan or within Middle Eastern context. The Arabic version was validated by four referees of Al-Hussein Bin Talal University instructors who hold $\mathrm{PhD}$ degrees in Instructional Technology, Information Technology, Curriculum and Instruction and Statistics. The reliability of the questionnaire was calculated using Cronbach's Alpha Coefficient, as shown in Table 2: 
Table 2. Reliability of TPACK Domains

\begin{tabular}{llll}
\hline Domain & $\begin{array}{l}\text { N of } \\
\text { items }\end{array}$ & $\begin{array}{l}\text { Cronbach's } \\
\text { Alpha }\end{array}$ & $\begin{array}{l}\text { Pearson } \\
\text { correlation }\end{array}$ \\
\hline Technological Knowledge (TK) & 10 & 0.947 & $0.927^{* *}$ \\
Content Knowledge (CK) & 8 & 0.637 & $0.810^{* *}$ \\
Pedagogical Knowledge (PK) & 11 & 0.918 & $0.282^{*}$ \\
Pedagogical Content Knowledge (PCK) & 5 & 0.616 & $0.853^{* *}$ \\
Technological Content Knowledge (TCK) & 6 & 0.930 & $0.276^{*}$ \\
Technological Pedagogical Knowledge (TPK) & 11 & 0.962 & $0.925^{* *}$ \\
Technological Pedagogical Content Knowledge (TPCK) & 7 & 0.863 & $0.874^{* *}$ \\
Total of Readiness & 58 & 0.949 & \\
\hline
\end{tabular}

** Correlation is significant at the 0.01 level (2-tailed); * Correlation is significant at the 0.05 level (2-tailed)

Measurement scale of the tool was transformed into five levels of readiness as shown in table 3 :

Table 3. Scaling Readiness Levels

\begin{tabular}{lllll}
\hline Strongly don't agree & Don't agree & Neutral & Agree & Strongly agree \\
\hline 1 & 2 & 3 & 4 & 5 \\
$1-1.80$ & $1.81-2.60$ & $2.61-3.40$ & $3.41-4.20$ & $4.21-5$ \\
Very weak readiness & Weak readiness & Medium readiness & High readiness & Very high readiness \\
\hline
\end{tabular}

\subsection{The Research Design}

To answer the study questions, teachers participated in a brief workshop and read a brochure illustrating augmented reality concept, design, webhosts and usage in teaching and learning situations regarding science. The brochure was distributed after measuring their readiness by (TPACK). Teachers were given three weeks to feel free to communicate with each other and use augment reality before applying the measurement tool (TPACK) for collecting data about their readiness for integrating augmented reality. The study procedures can be mapped as the following:

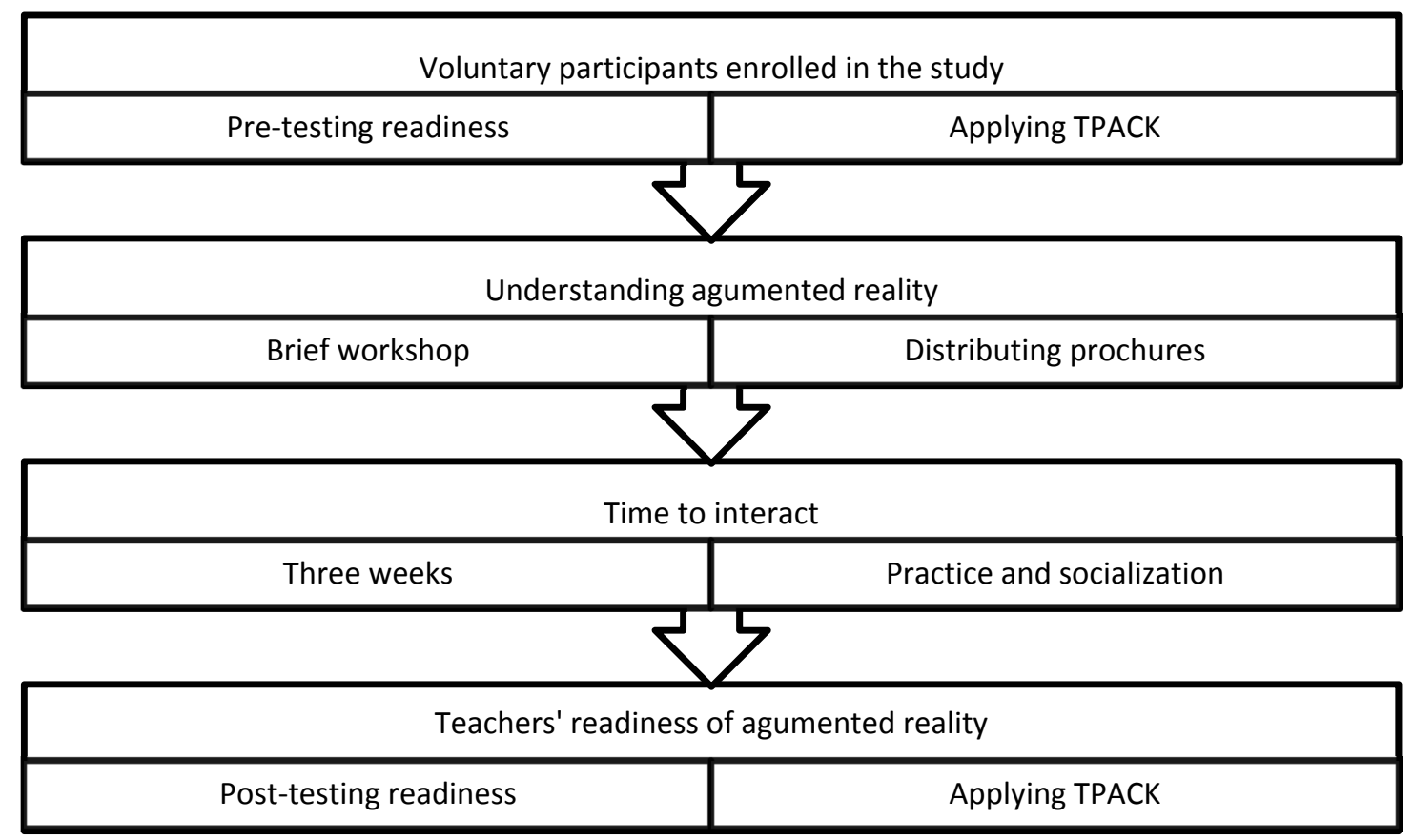

Figure 1. The Design of the Study 


\subsection{Data Analysis}

The gathered ratio data classified and analyzed to answer the study question. Hence the classified variables have one, two or three levels; different types of statistical procedures were used: Paired sample (related means) t-test was used to answer the first question, while ANCOVA used for answering the second and third question.

\section{Finding and Discussion}

The Analyses of the resulting ratio data were performed using descriptive statistics. Descriptive measures including means and standard deviations for TPACK domains were calculated to answer the questions of the study. These descriptive statistical measures were also tabulated and reported for classifying the variables (gender and years of experience) to determine the teachers' readiness for integrating augmented reality according to TPACK framework as shown in Table 4:

Table 4. Results of Pre/Post Readiness

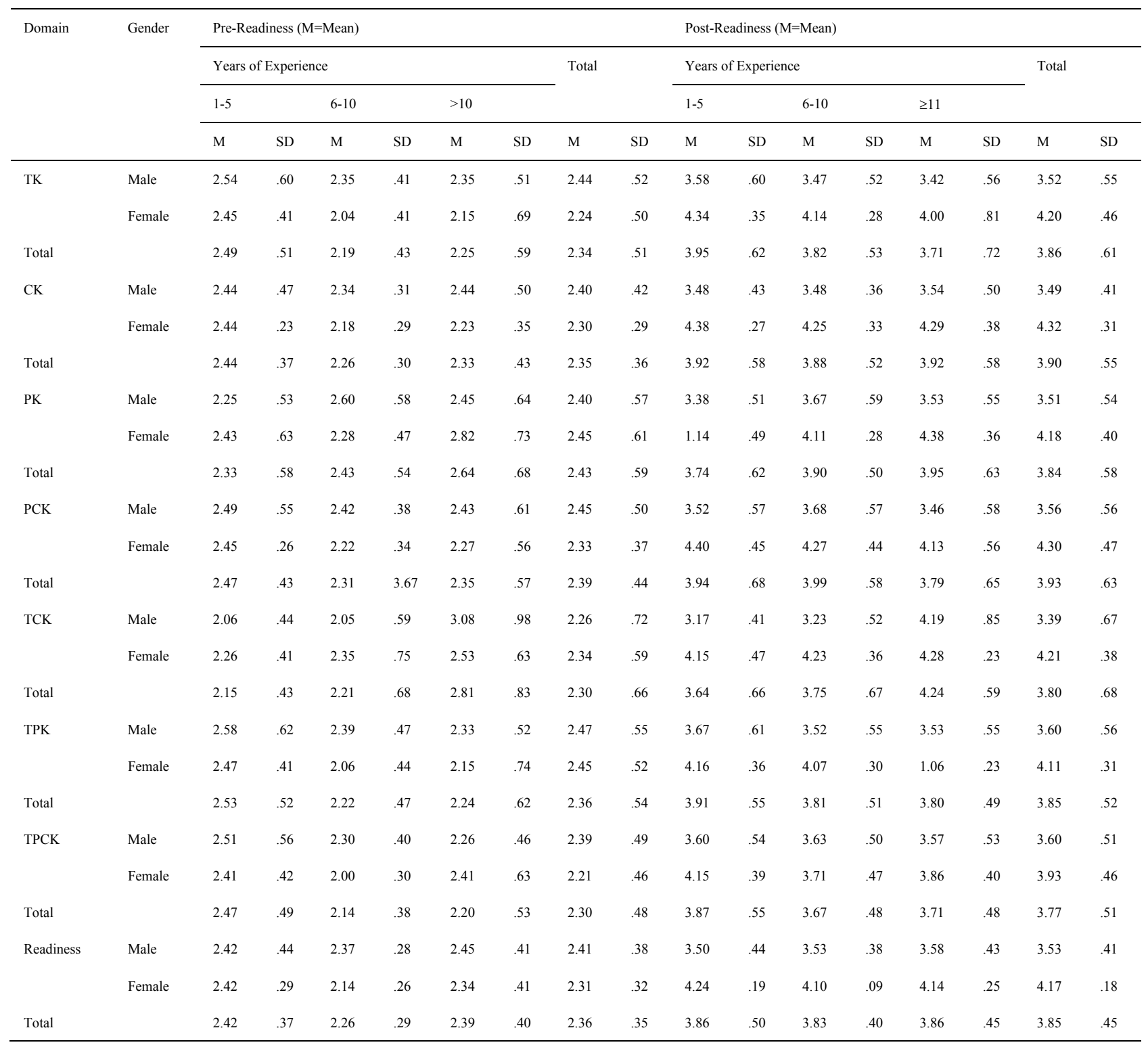


Results according to the questions of the study were as follow:

Results of Q1: What are the changes of readiness degree of in-service science teachers in Ma'an Directorate for integrating augmented reality in teaching according to TPACK framework and its domains?

Means and standard deviations were calculated at the perlpost measurement of teachers' readiness according to TPACK frame and its Domains, while the analyses of Paired sample t-test for means differences with $(\mathrm{df}=59)$ where used to determine the teacher's changes of readiness in integrating Augmented Reality in teaching:

Table 5. Results of Paired Sample T-Test

\begin{tabular}{|c|c|c|c|c|c|c|c|c|c|c|}
\hline \multirow[t]{2}{*}{ Domains } & \multicolumn{2}{|c|}{$\begin{array}{l}\text { Pre } \\
\text { Readiness }\end{array}$} & \multirow{2}{*}{$\begin{array}{l}\text { Pre } \\
\text { Readiness } \\
\text { Degree }\end{array}$} & \multicolumn{2}{|c|}{$\begin{array}{l}\text { Post } \\
\text { Readiness }\end{array}$} & \multirow{2}{*}{$\begin{array}{l}\text { Post } \\
\text { Readiness } \\
\text { Degree }\end{array}$} & \multicolumn{2}{|c|}{ Correlation } & \multirow[t]{2}{*}{$\mathrm{T}$ value } & \multirow[t]{2}{*}{ Sig } \\
\hline & Mean & SD & & Mean & SD & & $\mathrm{R}$ & Sig & & \\
\hline TK & 2.34 & .51 & weak & 3.86 & .61 & high & .485 & $.000(a)$ & 20.451 & $.000(a)$ \\
\hline $\mathrm{CK}$ & 2.35 & .36 & & 3.90 & .55 & & .300 & .020 & 21.383 & $.000(a)$ \\
\hline PK & 2.43 & .59 & & 3.84 & .58 & & .734 & $.000(a)$ & 25.731 & $.000(a)$ \\
\hline PCK & 2.39 & .44 & & 3.93 & .63 & & .466 & $.000(a)$ & 20.680 & $.000(a)$ \\
\hline TCK & 2.30 & .66 & & 3.80 & .68 & & .702 & $.000(a)$ & 22.486 & $.000(a)$ \\
\hline TPK & 2.36 & .54 & & 3.85 & .52 & & .543 & $.000(a)$ & 22.730 & $.000(a)$ \\
\hline TPCK & 2.30 & .48 & & 3.77 & .51 & & .659 & $.000(a)$ & 27.863 & $.000(a)$ \\
\hline Readiness & 2.36 & .35 & weak & 3.85 & .45 & high & .474 & $.000(a)$ & 27.530 & $.000(a)$ \\
\hline
\end{tabular}

Paired sample t-test revealed that there are significant differences at $\alpha \leq 0.05$ between the means of teachers' readiness for integrating Augmented Reality according to TPACK framework and all of its domains. Thus, the in-service science teachers in Ma'an Directorate readiness for integrating augmented reality in teaching according to TPACK framework and its domains have been changed positively after understanding augmented realty when enrolled in a workshop presented augmented realty.

Teachers' readiness has been shifted from weak readiness $(\mathrm{M}=2.36)$ to a high readiness $(3.85)$ and the total and all domains. Those findings show that science teachers have high competencies when they have the opportunity to explore different approaches on the basis of technologies, as the changes of readiness degrees were in all TPACK domains, which can be attributed to their competencies which have been developed by workshops in which they participated beside the three weeks of practicing augmented realty and interact with each other socially.

Based on these results, it appears that the teachers' readiness is high, but the obstacles are still having its role this region, as Jwaifell, Abu-Omar, and Al-Tarawneh (2018, p 863) pointed:

"Teachers have 24 classes every week, which is considered a very high load and they are restricted to a low range of pedagogies that are supervised by the administration. On the other hand, not all parents have an open mind for new methodologies of learning and teaching nor all of them can afford smart phones to their children. The Ministry of Education in Jordan is working within a very humble budget to reform and organize curriculum based on this kind of technology and pedagogical methodologies"

Ministry of education in Jordan have to rethink of its budget for more attention to the new era of technologies to find its way in students classrooms, it is not the matter of teachers' competencies more than finding funds to do the work .

Results of Q2: Do malelfemale in-service science teachers in Ma'an Directorate differ in their readiness for integrating augmented reality in teaching according to TPACK framework and its domains?

To answer the second question, means and standard deviations were calculated to examine the differences of readiness according to their gender: 
Table 6. Means and Standard Deviations According to Gender of Teachers

\begin{tabular}{lllllllll}
\hline \multirow{2}{*}{ Domains } & \multicolumn{3}{l}{ Pre Measurements } & \multicolumn{4}{c}{ Post Measurements } \\
\cline { 2 - 9 } & \multicolumn{1}{l}{ Male } & \multicolumn{3}{c}{ Female } & \multicolumn{3}{c}{ Male } & \multicolumn{3}{c}{ Female } \\
\cline { 2 - 9 } & Mean & SD & Mean & SD & Mean & SD & Mean & SD \\
\hline TK & 2.44 & .52 & 2.24 & .50 & 3.52 & .55 & 4.20 & 0.46 \\
CK & 2.40 & .42 & 2.30 & .29 & 3.49 & .41 & 4.32 & .31 \\
PK & 2.40 & .57 & 2.45 & .61 & 3.51 & .54 & 4.18 & .40 \\
PCK & 2.45 & .50 & 2.33 & .37 & 3.56 & .56 & 4.30 & .47 \\
TCK & 2.26 & .72 & 2.34 & .59 & 3.39 & .67 & 4.21 & .38 \\
TPK & 2.47 & .55 & 2.45 & .52 & 3.59 & .56 & 4.11 & .31 \\
TPCK & 2.39 & .49 & 2.21 & .46 & 3.60 & .51 & 3.93 & .46 \\
Readiness & 2.41 & .38 & 2.31 & .32 & 3.53 & .41 & 4.17 & .18 \\
\hline
\end{tabular}

Table 6 shows observed differences between the means of readiness for integrating augmented reality in teaching according to gender of teachers. ANCOVA was conducted to examine means differences as shown in Table 7:

Table 7. ANCOVA Summery According to Gender of Teachers

\begin{tabular}{|c|c|c|c|c|c|c|}
\hline \multicolumn{2}{|c|}{ Source of Variance } & Sum of Squares & $\mathrm{df}$ & Mean Square & $\mathrm{F}$ & Sig. \\
\hline \multirow[t]{3}{*}{ TK } & Pre-TK & 8.119 & 1 & 8.119 & 86.036 & $.000(a)$ \\
\hline & Gender & 9.989 & 1 & 9.989 & 83.708 & $.000(a)$ \\
\hline & Error & 6.802 & 57 & 0.119 & & \\
\hline \multirow[t]{3}{*}{ CK } & Pre-CK & 2.997 & 1 & 2.997 & 36.254 & $.000(a)$ \\
\hline & Gender & 11.593 & 1 & 11.593 & 140.255 & $.000(a)$ \\
\hline & Error & 4.712 & 57 & 0.083 & & \\
\hline \multirow[t]{3}{*}{ PK } & Pre-PK & 10.008 & 1 & 10.008 & 183.438 & $.000(a)$ \\
\hline & Gender & 5.050 & 1 & 5.050 & 110.884 & $.000(a)$ \\
\hline & Error & 3.110 & 57 & 0.055 & & \\
\hline \multirow[t]{3}{*}{ PCK } & Pre-PCK & 7.342 & 1 & 7.342 & 52.851 & $.000(a)$ \\
\hline & Gender & 10.478 & 1 & 10.478 & 75.423 & $.000(a)$ \\
\hline & Error & 7.918 & 57 & 0.139 & & \\
\hline \multirow[t]{3}{*}{ TCK } & Pre-TCK & 11.993 & 1 & 11.993 & 130.501 & $.000(a)$ \\
\hline & Gender & 8.492 & 1 & 8.492 & 92.400 & $.000(a)$ \\
\hline & Error & 5.238 & 57 & 0.092 & & \\
\hline \multirow[t]{3}{*}{ ТPK } & Pre-TPK & 6.923 & 1 & 6.923 & 77.019 & $.000(a)$ \\
\hline & Gender & 6.173 & 1 & 6.173 & 68.669 & $.000(a)$ \\
\hline & Error & 5.124 & 57 & 0.090 & & \\
\hline \multirow[t]{3}{*}{ TPCK } & Pre-TPCK & 8.244 & 1 & 8.244 & 86.929 & $.000(a)$ \\
\hline & Gender & 3.229 & 1 & 3.229 & 37.046 & $.000(a)$ \\
\hline & Error & 5.406 & 57 & 0.095 & & \\
\hline \multirow[t]{3}{*}{ Readiness } & Pre-Readiness & 4.136 & 1 & 4.136 & 147.008 & $.000(a)$ \\
\hline & Gender & 7.659 & 1 & 7.659 & 272.255 & $.000(a)$ \\
\hline & Error & 1.604 & 57 & 0.028 & & \\
\hline
\end{tabular}

Results of the ACNOVA revealed significant differences at $\alpha \leq 0.05$ between the means of prelpost means according to their gender at the domains (TK, CK, PK, PCK, TCK TPK, TPCK and Readiness) due to female teachers, which means that female teachers' readiness is higher than male teachers. Thus, female in-service science teachers in Ma'an Directorate differ in their readiness for integrating augmented reality in teaching according to TPACK framework and its domains.

This result can be referred to female teachers' culture, where they have more social relations than male teachers, beside the competition between them as far as of the researchers' experience. In this matter the Ministry of Education in Jordan need to promote more crediting for teachers and consider a budget for using augmented realty.

Results of Q3: Do years of experience of in-service science teachers in Ma'an Directorate have an effect on their readiness for integrating augmented reality in teaching according to TPACK framework and its 


\section{domains?}

To answer the third question, means and standard deviations were calculated to examine the differences changes of readiness according to years of experience as shown in Table 8:

Table 8. Means and Standard Deviations According to Years of Experience

\begin{tabular}{cccccccc}
\hline \multirow{2}{*}{ Domains } & Readiness Measurement & \multicolumn{2}{c}{ 1-5 years. N=27 } & \multicolumn{2}{c}{6 -10 years. N=21 } & \multicolumn{2}{c}{ 11 years and more. N=12 } \\
\cline { 2 - 7 } & & Mean & SD & Mean & SD & Mean & SD \\
\hline TK & Pre & 2.49 & .51 & 2.19 & .43 & 2.25 & .59 \\
& Post & 3.95 & .62 & 3.82 & .53 & 3.71 & .73 \\
CK & Pre & 2.44 & .37 & 2.26 & .30 & 2.33 & .43 \\
& Post & 3.92 & .58 & 3.88 & .52 & 3.92 & .58 \\
PK & Pre & 2.33 & .58 & 2.43 & .54 & 2.64 & .68 \\
& Post & 3.74 & .62 & 3.90 & .50 & 3.95 & .63 \\
PCK & Pre & 2.47 & .43 & 2.31 & 3.67 & 2.35 & .57 \\
& Post & 3.94 & .68 & 3.99 & .58 & 3.79 & .65 \\
TCK & Pre & 2.15 & .43 & 2.21 & .68 & 2.81 & .83 \\
& Post & 3.64 & .66 & 3.75 & .67 & 4.24 & .59 \\
TPK & Pre & 2.53 & .52 & 2.22 & .47 & 2.24 & .62 \\
& Post & 3.91 & .55 & 3.81 & .51 & 3.80 & .49 \\
TPCK & Pre & 2.47 & .49 & 2.14 & .38 & 2.20 & .53 \\
& Post & 3.87 & .55 & 3.67 & .48 & 3.71 & .48 \\
Readinessyyyyyyy & Pre & 2.42 & .37 & 2.26 & .29 & 2.39 & .40 \\
& Post & 3.86 & .50 & 3.83 & .40 & 3.86 & .45 \\
\hline
\end{tabular}

Table 8 shows observed differences between the means of readiness for integrating augmented reality in teaching according to years of experience of teachers. ANCOVA was conducted to examine means differences as shown in Table 9:

Table 9. ANCOVA Summery According to Years of Experience

\begin{tabular}{lllllll}
\hline Source of Variance & Sum of Squares & df & Mean Square & F & Sig. \\
\hline TK & Pre-TK & 4.824 & 1 & 4.824 & 16.248 & $.000(\mathrm{a})$ \\
& Years of Experience & 0.166 & 2 & 0.083 & 0.280 & .757 \\
CK & Error & 16.625 & 56 & 0.297 & & \\
& Pre-CK & 1.632 & 1 & 1.632 & 5.616 & $.000(\mathrm{a})$ \\
& Years of Experience & 0.036 & 2 & 0.018 & 0.062 & .939 \\
PK & Error & 16.269 & 56 & 0.291 & & \\
& Pre-PK & 10.315 & 1 & 10.315 & 63.845 & $.000(\mathrm{a})$ \\
& Years of Experience & 0.112 & 2 & 0.056 & 0.346 & .709 \\
PCK & Error & 9.048 & 56 & 0.162 & & \\
& Pre-PCK & 5.248 & 1 & 5.248 & 16.367 & $.000(\mathrm{a})$ \\
& Years of Experience & 0.439 & 2 & 0.220 & 0.685 & .508 \\
TCK & Error & 17.957 & 56 & 0.321 & & \\
& Pre-TCK & 10.530 & 1 & 10.530 & 43.456 & $.000(\mathrm{a})$ \\
& Years of Experience & 0.161 & 2 & 0.080 & 0.332 & .719 \\
TPK & Error & 13.569 & 56 & 0.242 & & \\
& Pre-TPK & 4.623 & 1 & 4.623 & 23.028 & $.000(\mathrm{a})$ \\
& Years of Experience & 0.053 & 2 & 0.027 & 0.133 & .876 \\
TPCK & Error & 11.243 & 56 & 0.201 & & \\
& Pre-TPCK & 6.160 & 1 & 6.160 & 40.031 & $.000(\mathrm{a})$ \\
& Years of Experience & 0.017 & 2 & 0.008 & 0.054 & .948 \\
Readines & Error & 8.618 & 56 & 0.154 & & \\
& Pre-Readiness & 2.737 & 1 & 2.737 & 16.670 & $.000(\mathrm{a})$ \\
& Years of Experience & 0.069 & 2 & 0.034 & 0.209 & .812 \\
\hline
\end{tabular}


Results of the ACNOVA revealed no significant differences at $\alpha \leq 0.05$ between the means of prelpost means according to their gender at the domains (TK, CK, PK, PCK, TCK TPK, TPCK and Readiness) due to years of experience of teachers, which means that years of teachers experience didn't affect the change of their readiness.

Findings of the study are very consistent with the findings of related studies. This study revealed the high degree of teachers' readiness for using Augmented Reality after the workshop they took, which reflects their positive perceptions of using it. Overall, findings of related studies about Augmented Reality showed its importance and how it can change attitudes toward using it as an effective tool in education.

\section{Conclusion}

This study revealed the changes in teachers' of science readiness to integrate Augmented Reality in teaching. These findings have implications for efforts to use technologies in teaching as an effective tool. The results of this descriptive study help to clarify the aptitude of in-service teachers to use new technologies as Augmented Realty. For example policy makers can take advantages of technology and integrating them into learning situations and give more attention in considering a budget for using technologies in schools.

\section{References}

Abu Baker, Juliana., Goplan, Valarmathie., Zulkifli, Abdul Nasir., \& Alwi, Asmidah. (2016). Design and Development of Mobile Augmented Reality for Physsics Experiment, 5th international Conference, i-USEr 2018, Puchong, Malaysia, August 28-30, 2018, Proceedings. https://doi.org/10.1007/978-981-13-1628-9

Agbo-Egwu, A. O., Abah, J. A., \& Abakpa, B. O. (2018). Perceptions of tech-augmented learning in basic mathematics among university students: A case of matrix algebra tools. International Refereed Journal of Arts, Science \& Commerce, 6(1), 121-131.

Al Doghmi, A., Al-Shalabi, H., Jwaifell, M., Andraws, S., Awajan, A., \& Alrabea, A. I. (2013). The academic use of social networks among university students in Jordan. International Journal of Computer Science Issues, 10(5), 134-141.

Almalaheem, Safa. (2016). The Degree of Readiness of Ma'an Governorate Physics Teachers in Integrating E-Learning Types in Teaching, According to Technological Pedagogical Content Knowledge Framework (TPACK). Unpublished theses. Alhussein Bin Talal University. Jordan.

Azuma, Ronald. (1997). A Survey of Augmented Reality. Presence, 6(4), 355-385. https://doi.org/10.1162/pres.1997.6.4.355

Cabero, J., \& Barroso, J. (2016). The educational possibilities of Augmented Reality. Journal of New Approaches in Educational Research, 5(1), 44-50. https://doi.org/10.7821/naer.2016.1.140

Chai, C., Koh, J., Tsai, C., \& Tan, L. (2011). Modeling primary school pre-service teachers' Technological Pedagogical ContentKnowledge (TPACK) for meaningful learning with information and communication technology (ICT). Computers \& Education, 57(1), 1184-1193. https://doi.org/10.1016/j.compedu.2011.01.007

Cox, S., \& Graham, C. R. (2009). Diagramming TPACK in practice: Using an elaborated model of the TPACK framework to analyze and depict teacher knowledge. TechTrends: Linking Research \& Practice to Improve Learning, 53(5), 60-69. https://doi.org/10.1007/s11528-009-0327-1.

Delello, Julie. (2014). Insight from pre-service teachers using science-based augmented reality. J. Compu. Edu., 1(4), 295-311. https://doi.org/10.1007/s40692-014-0021-y

Goplan, Valarmathie., Zulkifli, Abdul Nasir \& Abu Baker, Juliana. (2016). A study of students' motivation using the aygmented reality science textbook. Proceedings of the International Conference on Applied Science and Technology 2016 (ICAST’16) AIP Conf. Proc. 1761, 020040-1-020040-6; https://doi.org/10.1063/1.4960880. Published by AIP Publishing. 978-0-7354-1419-8/\$30.00

Goplan, Valarmathie., Zulkifli, Abdul Nasir., Mohamed, Nur., Alwi, Asmidah., Mat, Ruzinoor., Abu Baker, Juliana \& Saidin, Aeni. (2015). Evaluation of E0star: An Enhanced Science textbook using Augmented Reality among Lower Secondary School Students. Jurnal Technology, 77(29), 55-61. https://doi.org/10.11113/jt.v77.6813

Groth, R., Spickler, D., Bergner, J., \& Bardzell, M. (2009). A qualitative approach to assessing technological pedagogical content knowledge. Contemporary Issues in Technology and Teacher Education (CITE Journal), 
9(4), 392-411.

Hechter, R. P. (2012). Pre-service teachers' maturing perceptions of a TPACK-framed signature pedagogy in science education. Computers in the Schools, 29(1-2), 53-69. https://doi.org/10.1080/07380569.2012.657999

Jang, S.-J. (2010). Integrating the interactive whiteboard and peer coaching to develop the TPACK of secondary science teachers. Computers \& Education, 55(4), 1744-1751. https://doi.org/10.1016/j.compedu.2010.07.020

Jang, S.-J., \& Chen, K. C. (2010). From PCK to TPACK: Developing a transformative model for preservice science teachers. Journal of Science Education and Technology, 19(6), 553-564. https://doi.org/10.1007/s10956-010-9222-y

Jang, S.-J., \& Tsai, M.-F. (2012). Exploring the TPACK of Taiwanese elementary mathematics and science teachers with respect to use of interactive whiteboards. Computers \& Education, 59(2), 327-338. https://doi.org/10.1016/j.compedu.2012.02.003

Jang, S.-J., \& Tsai, M.-F. (2013). Exploring the TPACK of Taiwanese secondary school science teachers using a new contextualized TPACK model. Australasian Journal of Educational Technology, 29(4), 566-580. https://doi.org/10.14742/ajet.282

Jwaifell, M., Abu-Omar, A., \& Al-Tarawneh, M. (2018). The Readiness of Arabic Language Teachers for Integrating Flipped Classroom: Case of Ma'an. International Journal of Instruction, 11(4), 855-868. https://doi.org/10.12973/iji.2018.11454a

Jwaifell, M., Al-Shalabi, H., Andraws, S., Awajan, A., \& Alrabea, A. (2013). The intensity of social networks group use among the students of Jordanian universities. Global Journal of Computer Science and Technology Network, Web \& Security, 13(2), 1-8.

Kaufmann, Hannes \& Dünser, A. (2007). "Summary of Usability Evaluations of an Educational Augmented Reality Application," in HCI International Conference (HCII 2007). vol. 14, LNCS 4563, R. Shumaker, Ed., Beijing, China: Springer-Verlag Berlin Heidelberg, pp. 660-669. https://doi.org/10.1007/978-3-540-73335-5_71

Kaufmann, Hannes \& Schmalstieg, D. (2003). Mathematics and geometry education with collaborative augmented reality. Computers \& Graphics, 27, 339-345. https://doi.org/10.1016/s0097-8493(03)00028-1

Ke, Fengfeng \& Hsu, Yu-Chang. (2015). Mobile Augmented-Reality Artifact Creation as a Component of Mobile Computer-Supported Collaborative Learning. The Internet and Higher Education, 26, 33-41. https://doi.org/10.1016/j.iheduc.2015.04.003

Khan, S. (2011). New pedagogies on teaching science with computer simulations. Journal of Science Education and Technology, 20(3), 215-232.

Koehler, M. J., \& Mishra, P. (2009). What is technological Pedagogical content knowledge? Contemporary Issues in Technology and teacher Education, 9(1), 60-70.

Leinhard, G., \& Greeno, J. (1986). The cognitive skills of teaching. Journal of Educational Psychology, 78(2), 75-95.

Lin, T.-C., Tsai, C.-C., Chai, C.-S., \& Lee, M.-H. (2013). Identifying science teachers' perceptions of technological pedagogical and content knowledge (TPACK). Journal of Science Education and Technology, 22(3), 325-336. https://doi.org/10.1007/s10956-012-9396-6

Liu, D., Jenkins, S. A., Sanderson, P. M., Perry, F., \& Russell, W. J. (2010, April). Monitoring with Head-Mounted Displays in General Anesthesia: A Clinical Evaluation in the Operating Room. Society for Technology in Anesthesia, 110(4), 1032-1038. https://doi.org/10.1213/ANE.0b013e3181d3e647

Luckin, Rosemary \& Fraser Danae. (2011). Limitless or pointless?: An Evaluation of Augmented Technology Reality in the School and Home. Int, J. Technology Enhanced Learning, 3(5). https://doi.org/10.1504/ijtel.2011.042102

Ministry of Education. Queen Rania Center for Education and Information Technolog. Vission and Mission. Retrieved from http://www.moe.gov.jo/en/node/18777

Mishra, P., \& Koehler, M. J. (2006). Technological pedagogical ConTenT Knowledg: A Framework for Teacher knowledge. Teachers college Records, 108(6), 1017-1054. https://doi.org/10.1111/j.1467-9620.2006.00684.x

Niess, M. L., Ronau, R. N., Shafer, K. G., Driskell, S. O., Harper S. R., Johnston, C., Browning, C., Özgün-Koca, S. A., \& Kersaint, G. (2009). Mathematics teacher TPACK standards and development model. Contemporary 
Issues in Technology and Teacher Education, 9(1), 4-24.

Rogers, Y., Price, S., Randell, C., Stanton Fraser, D., Weal M., \& Fitzpatrick, G. (2005). Ubi-learning integrates indoors and outdoor experiences. Communications of the ACM, 48(1), 55-59. https://doi.org/10.1145/1039539.1039570.

Shulman, L. S. (1987). Knowledge and teaching: Foundations of the new reform. Harvard Educational Review, 57(1), 1-23. https://doi.org/10.17763/haer.57.1.j463w79r56455411

Spiro, R, J., Feltovich, P, J., \& Coulson, R, L. (1991). Knowledge representation, content specification, and the development of skill in situation-knowledge assembly: some constructivist issues as they relate to cognitive flexibility theory and hyper text. Educational technology, 31(9), 22-25.

Swidan, A., Al-Shalabi, H., Jwaifell, M., Awajan, A., \& Alrabea, A. (2013). The intensity and the factors affecting the use of social network sites among the students of Jordanian universities. International Journal of Computer Science Issues, 10(1), 492-498.

Trautmann, N. M., \& MaKinster, J. G. (2010). Flexibly adaptive professional development in support of teaching science with geospatial technology. Journal of Science Teacher Education, 21(3), 351-370. https://doi.org/10.1007/s10972-009-9181-4

White, Bruce \& Geer, Ruth. (2013). Preservice teachers experience with online modules about PACK. Australian Educational Computing, 27(3), 124-132.

Yuen, S., Yaoyuneyong, G., \& Johnson, E. (2011). Augmented reality: An overview and five directions for AR in education. Journal of Educational Technology Development and Exchange, 4(1), 119-140. https://doi.org/10.181785/jetde.0401.10 